\title{
Evolutionary geochemical patterns of Late Cretaceous to Eocene arc magmatic rocks in North Chile: implications for Archean crustal growth
}

\author{
M. R. Haschke \\ Dept. of Geophysics and Planetary Sciences, Tel Aviv University, 69978 Tel Aviv, Israel \\ Present address: GeoForschungsZentrum Potsdam, Telegrafenberg C220, 14473 Potsdam, Germany \\ (Email: mrh@geo.gfz-potsdam.de)
}

Received: 20 October 2000 - Revised: 5 March 2002 - Accepted: 7 May 2002

\begin{abstract}
Repeated eastward shifting of subduction-related magmatism between Jurassic and Present generated a collage of four magmatic arcs in North Chile $\left(21-26^{\circ} \mathrm{S}\right)$. Focussing on the Late Cretaceous-Eocene arc, this study explores the evolution of geochemical and isotopic signatures of arc magmatic rocks through time. Temporal geochemical variations include systematic steepening of heavy rare earth element patterns and increasing $\mathrm{Sr}$ and $\mathrm{Al}$ contents with decreasing age. Gradually increasing $\mathrm{La} / \mathrm{Yb}$ and $\mathrm{Sr} / \mathrm{Y}$ ratios between $\sim 78 \mathrm{Ma}$ and $39 \mathrm{Ma}$ appear to monitor gradual crustal thickening by newly underplated basaltic crust, whereas sharply rising $\mathrm{La} / \mathrm{Yb}$ and $\mathrm{Sr} / \mathrm{Y}$ ratios in late Eocene syn/post-tectonic granites and granodiorites reflect Incaic (38.5 Ma) shortening and thickening of arc crust to $\sim 45 \mathrm{~km}$, consistent with regional tectonic field constraints. Support for the timing and magnitude of crustal thickening comes from similarities with chemical signatures from the modern southern volcanic zone (SVZ), from trace element modeling and from regional geologic constraints. On the scale studied, the geochemical variations presented correspond to a temporal transition from common Phanerozoic island-arc type to Archean type high-Al trondhjemite-tonalite-dacite (TTD) and granodiorite (TTG) crust. Comparisons with adjacent older and younger Andean magmatic arcs in this region show similar geochemical patterns; the thicker the crust the more high-Al TTD/TTG like the chemical signatures are. On the larger scale of the Andean orogeny, our results support earlier models of Archean crustal growth which suggest that large portions of early Earth's high-Al TTD/TTG type continental crust may have been generated by recycling mafic underplate of thick orogenic crust.
\end{abstract}

\section{Introduction}

Geochemical and experimental petrological work indicate that early Earth's continental trondhjemite- tonalite-dacite (TTD) and granodiorite (TTG) crust was generated by partial melting of a basaltic protolith transformed into a garnet- bearing amphibolite or eclogite, yet the geodynamic setting is subject of controversy (Martin, 1999). Debate centers on the problem of wether Archean TTD/TTG suites were generated by melting of (1) subducting basaltic ocean crust (e.g. Defant and Drummond; 1990; Martin, 1999), or (2) contamination within deep (underplated) basalt beneath overthickened $(>40 \mathrm{~km})$ orogenic crust (e.g. Atherton and Petford, 1993; Feeley and Hacker, 1995; Petford and Atherton, 1996; Petford and Gallagher, 2001; Haschke et al., 2002a). Both scenarios generate melts with geochemical signatures diagnostic of Archean high-Al TTD/TTG (i.e. low Yb and Y concentrations, high $\mathrm{Al}, \mathrm{Na}$ and $\mathrm{Sr}$ contents, and high $\mathrm{La} / \mathrm{Yb}$ and $\mathrm{Sr} / \mathrm{Y}$ ratios). Although most Phanerozoic dacite-granodiorite (island-arc type) suites are high in $\mathrm{Yb}$ and $\mathrm{Y}$, with low $\mathrm{Al}$, $\mathrm{Na}$ and $\mathrm{Sr}$ contents, and low $\mathrm{La} / \mathrm{Yb}$ and $\mathrm{Sr} / \mathrm{Y}$ ratios. Modern TTD/TTG type rocks are rare, but where they do exist they simulate the conditions that led to widespread crustal growth in the Archean and provide potential keys to unlock our basic understanding of continental evolution (Martin, 1999).

Slab melting during the Archean is perhaps more widely accepted as higher heat flow presumably induced rapid subduction of smaller and younger (hotter) plates, optimizing the conditions for slab melting. However, remelting (magmatic recycling) of mafic underplate at the base of overthickened orogenic crust is more controversial as it implies early growth and existence of an overall thick $(>40 \mathrm{~km})$ Archean crust. A detailed study of long-term subduction-related magmatism along an $\sim 500 \mathrm{~km}$ long section in the central Andean foreland may provide support for this rival hypothesis. I compiled major and trace element and $\mathrm{Sr}$ and $\mathrm{Nd}$ isotopic data for 501 samples of Andean magmatic rocks from North Chile (21-26 S) with ages from $200 \mathrm{Ma}$-Present. New analyses of Late Cretaceous-Eocene magmatic rocks are published in Haschke et al. (2002a). The complete data compilation is available upon request. It is by no means complete, but rather awaits further work as the interplay of geochemical and tectonic patterns presented may have a large impact on early Earth's crustal evolution models. 


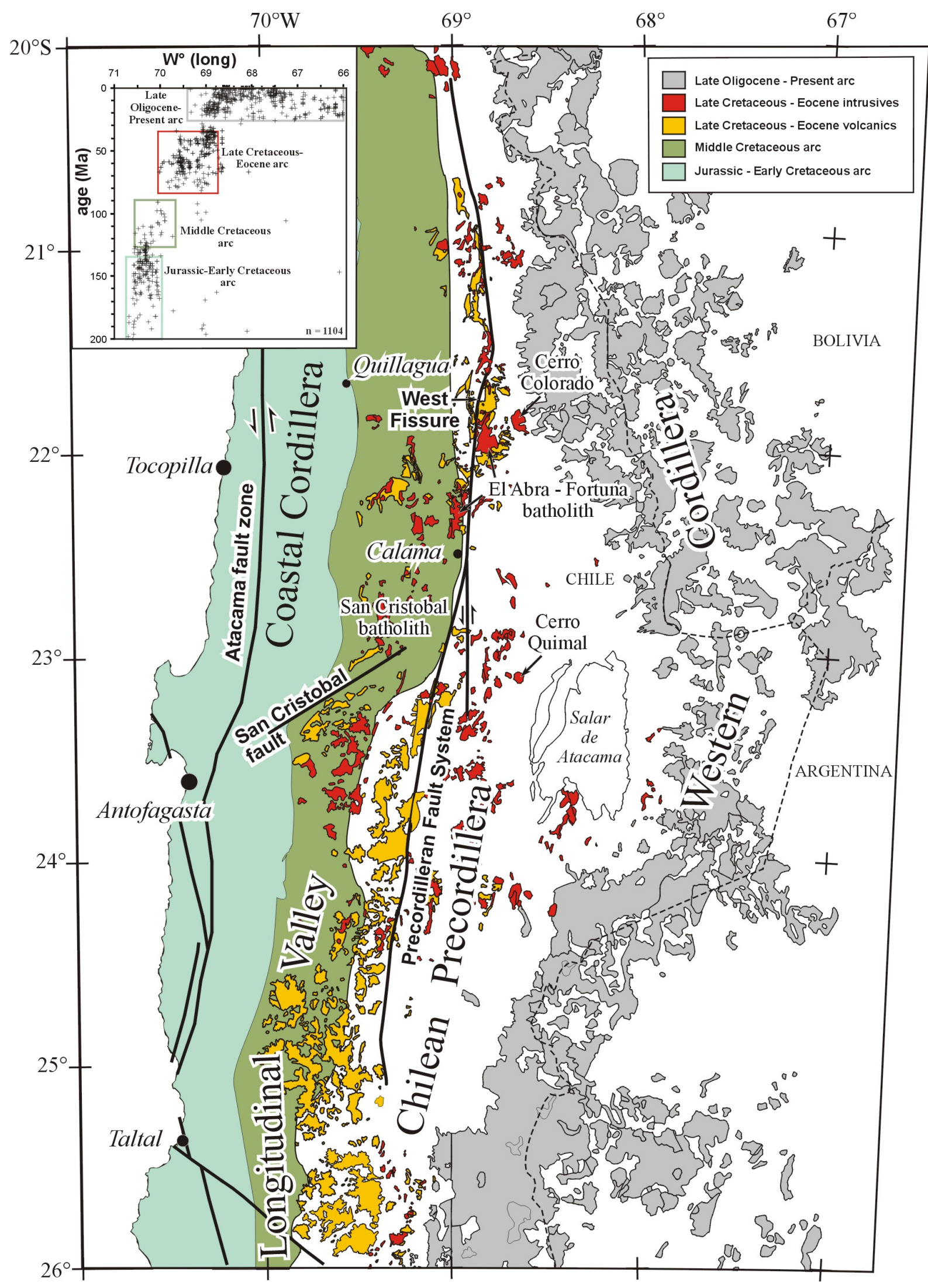

Fig. 1. Simplified geologic map of North Chile with distribution of Jurassic-Present arc magmatic rocks in the central Andean foreland. Black lines mark trench-linked strike slip fault zones in each arc system. Inset shows plot of age of central Andean magmatic rocks vs longitude (compiled by Scheuber et al., 1994). 


\section{Tectonic and geologic framework}

The study area forms the western foreland of the modern central Andean Western Cordillera volcanic arc in North Chile. Stepwise, eastward shifting arc magmatism from the Jurassic to the Present generated a collage of four largely parallel, eastward younging magmatic arcs (Coira et al., 1982; Scheuber et al., 1994; Fig. 1): the mainly Jurassic islandarc type chain along the present Coastal Cordillera, the more evolved mid-Cretaceous arc parallel to the Chilean Longitudinal Valley, the mature Late Cretaceous-Eocene continental arc largely corresponding to the Chilean Precordillera and the late Oligocene-late Miocene orogenic arc and modern Western Cordillera. Like a window to the past, this paleoarc magmatic assemblage is restricted to the central Andean foreland between $21^{\circ}-26^{\circ} \mathrm{S}$. North and south of these latitudes, the paleo and modern volcanic arcs merge into the main Cordillera. Systematic and clear geochemical patterns like the ones shown in this study cannot be produced north and south of this section.

The Mesozoic and Cenozoic tectonic history of North Chile $\left(21^{\circ}-26^{\circ} \mathrm{S}\right)$ is well established from earlier regional geologic studies (e.g. Reutter et al., 1991; Scheuber and Reutter, 1992; Döbel et al., 1992; Scheuber et al., 1994; Günther et al., 1998). Each paleo-magmatic episode ended simultaneously with major tectonic activity along the main-arc axis; either transtension and crustal stretching (Araucanian tectonic episode (135-130 Ma) in the Jurassic arc - Scheuber et al., 1994) or transpression and crustal shortening (Peruvian unconformity (90-80 Ma) - Scheuber et al., 1994; Incaic unconformity (38.5 Ma) - Döbel et al., 1992), followed by magmatic quiescence of 5-10 m.y. Subsequent arc magmatic activity established up to $100 \mathrm{~km}$ further to the east. The amount of crustal shortening and thickening tend to increase with decreasing age of each magmatic arc.

The first arc system of the Andean Cycle (Jurassic-Early Cretaceous arc) was built up since the Sinemurian in the area of the present Coastal Cordillera (Fig. 1). This arc is composed of lavas, mafic to felsic dikes, tuffs and large plutons of gabbroic to granodioritic composition. Most lavas are basaltic andesite flows interstratified with terrestrial and marine intercalations, indicating that the surface of this island-arc type volcanic chain was, more or less, at sea level (Scheuber and Reutter, 1992). Some volcanic products reach thicknesses of $\sim 10 \mathrm{~km}$ (e.g. near Antofagasta) suggesting substantial crustal subsidence. Numerous suites of high angle faults and orogen-parallel dikes ( $>40 \%$ of the outcropping rocks), together with deepening marine back-arc basins, suggest that the gain in crustal volume occurred in an overall extensional tectonic regime with (rift-like) filling of opening interstices by melt. Transtension was accomodated by tearing apart crustal blocks and transtensional strike-slip motion along the trench-linked Atacama fault zone (Fig. 1). There is no evidence of significant tectonic crustal thickening during this magmatic episode.

The tectonomagmatic history of the middle Cretaceous arc system is more enigmatic. Arc-magmatic rocks were em- placed in the subsiding back-arc basin of the previous, now magmatically inactive, (Jurassic) arc system and the lack of a significant angular unconformity between the sedimentary substrate and the lavas (Jensen, 1985) suggests that extensional tectonics continued up to the mid-Cretaceous. Only the last stage of this arc was accompanied by transpressive crustal shortening and subsequent strike-slip motions along the San Cristobal fault leading to intense folding and, in some places, to foliation and cleavage development in volcanic and sedimentary rocks (Scheuber and Reutter, 1992). The age of this deformation is constrained by radiometrically dated deformed rocks, by the post-deformational emplacement of radiometrically dated plutons (San Cristobal batholith; Maksaev, 1990), and by an angular unconformity between the deformed sequence and an overlying volcanic sequence of Late Cretaceous-Eocene age (90-80 Ma: Peruvian tectonic episode; Scheuber et al., 1994).

Unlike older Andean paleo-arcs in North Chile, the Late Cretaceous-Eocene arc tuffs, lavas and ignimbrites above this unconformity were deposited together with redbeds above the sea level. More than $3000 \mathrm{~m}$ of red-bed type conglomerates interstratified with marine intercalations are diagnostic of a considerable relief contrast between the arc and back-arc region. Late Cretaceous alkaline gabbros to diorites (Cerros Quimal and Colorado, Fig. 1) intruding the red-beds in this arc to back-arc transition are consistent with an extensional tectonic regime (Charrier and Reutter, 1994). In contrast, the youngest magmatic rocks of this paleo-arc system (El AbraFortuna batholith, Fig. 1) were generated simultaneously and subsequent to late Eocene Incaic transpressional deformation, which shortened the arc crust by about $9 \mathrm{~km}$ (or $14.5 \%$ tectonic crustal thickening, Günther et al., 1998). Like the older Andean arc systems, arc magmatic activity ceased after orogen-parallel transcurrent movements along the West Fissure (Precordilleran fault system; Reutter et al., 1991), and was reinstalled in the Late Oligocene/Early Miocene up to $100 \mathrm{~km}$ by the modern Western Cordillera volcanic arc. Maximum crustal thicknesses of $\sim 70 \mathrm{~km}$ beneath the present Andean volcanic arc are constrained by recent refraction experiments, broadband passive recording of earthquakes in the subducted plate, and modeling of the gravity field (Wigger et al., 1994). The results of my study illustrate how the major and trace element, and $\mathrm{Sr}$ and $\mathrm{Nd}$-isotopic compositions of Andean arc-magmatic rocks traced this long-term tectonic and magmatic evolution and progressive crustal thickening of the Andean convergent continental margin.

\section{Geochemical changes of late Cretaceous-Eocene main-arc magmatic rocks in North Chile $\left(21^{\circ}-26^{\circ} \mathrm{S}\right)$}

\subsection{Major and trace elements}

Late Cretaceous-Eocene arc magmatism in North Chile produced a larger volume calc-alkaline suite of medium to high$\mathrm{K}$ basaltic andesites to dacites and rhyolites, a smaller volume back-arc suite of alkaline gabbros to granodiorites, and 

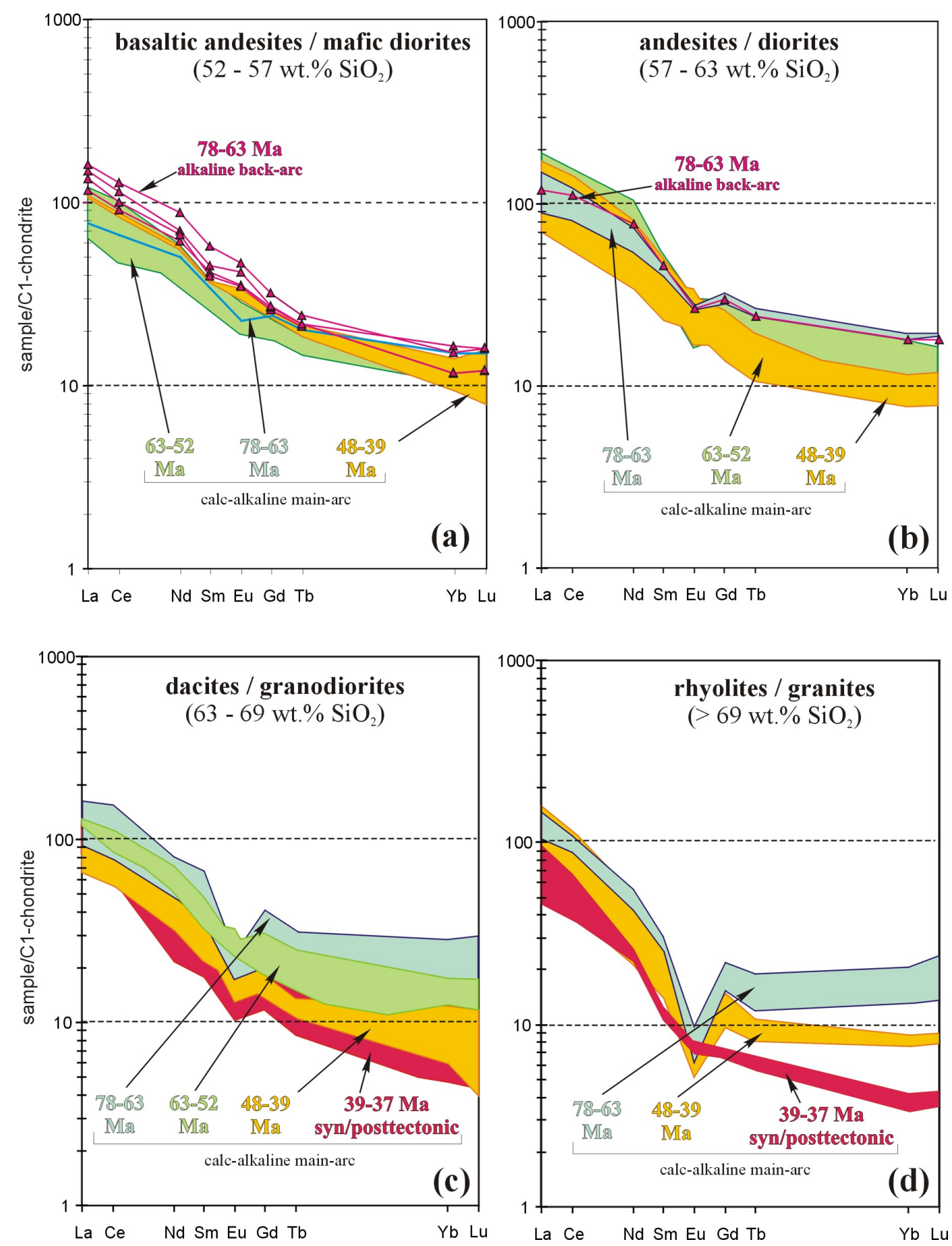

Fig. 2. REE patterns of Late Cretaceous-Eocene arc magmatic rocks in North Chile. (a) basaltic andesites and mafic diorites, (b) andesites and dorites, (c) dacites and granodiorites, (d) rhyolites and granites. Note increasing heavy $\mathrm{REE}$ fractionation with time and increasing $\mathrm{SiO}_{2}$ content.

some scattered calc-alkaline mafic andesitic centers aligned with across-arc fracture zones (Fig. 1). As is typical for most magmatic rocks of the central volcanic zone (CVZ) and the southern volcanic zone (SVZ), the high $\mathrm{Ba} / \mathrm{Nb}$ ratios $(>30)$ of Late Cretaceous-Eocene rocks from both the calc-alkaline and alkaline magmatic suites are consistent with primary melt generation from a metasomatized mantle wedge above a dehydrating subducting slab (e.g. Hildreth and Moorbath, 1988; Kay et al., 1991).

The study stresses that intermediate and silicic Late Cretaceous-Eocene arc magmatic rocks at equal $\mathrm{SiO}_{2}$ show compositional variations with decreasing age, such that the greatest chemical contrast within this arc system occurs between the oldest (Late Cretaceous) and the youngest (late 


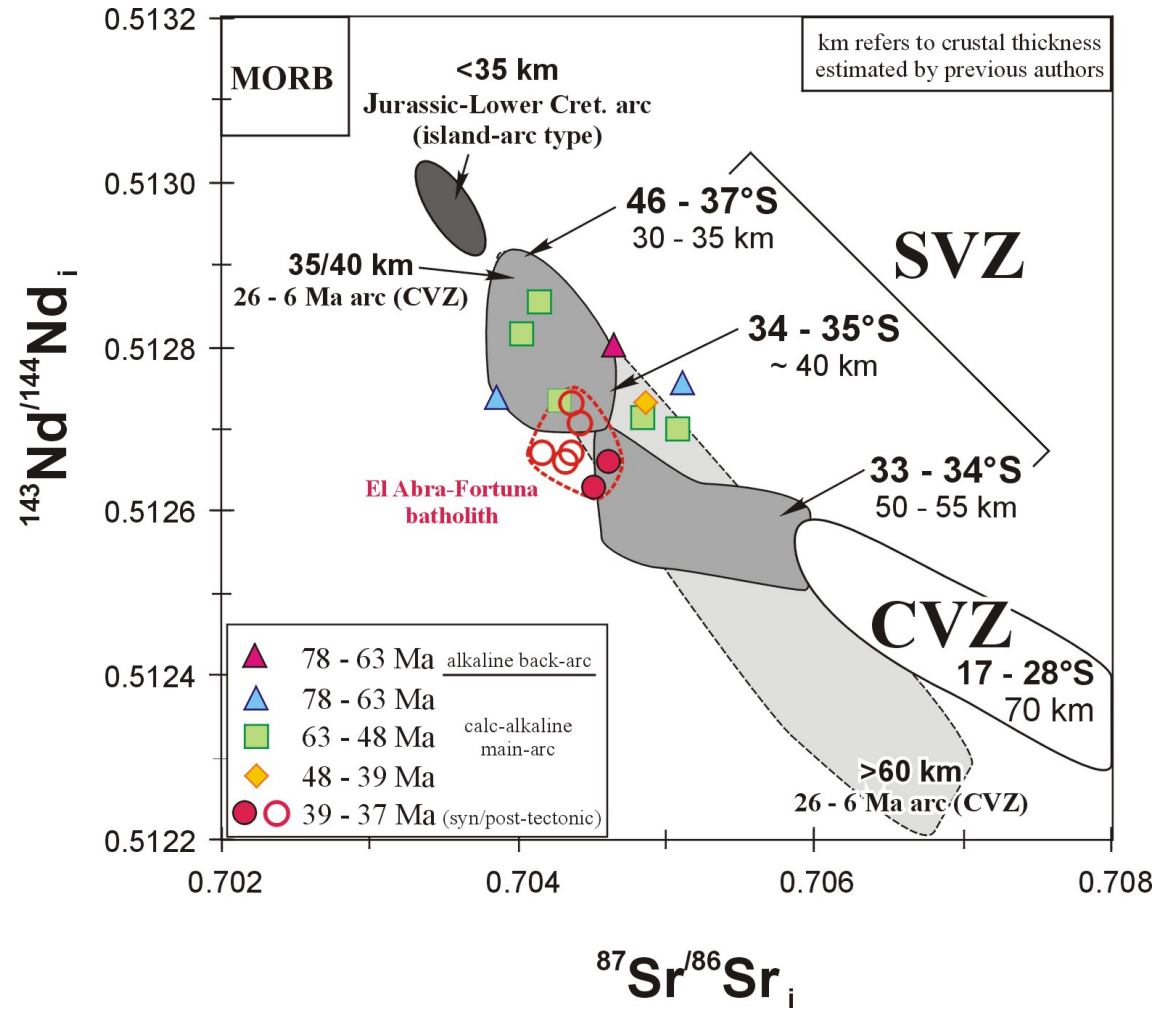

Fig. 3. Correlation of initial ${ }^{87} \mathrm{Sr} /{ }^{86} \mathrm{Sr}$ isotopic ratios vs initial ${ }^{143} \mathrm{Nd} /{ }^{144} \mathrm{Nd}$ isotopic ratios. Late Cretaceous-Eocene rocks partly overlap with $\mathrm{Sr}$ and $\mathrm{Nd}$ isotopic compositions from the SVZ between $37^{\circ} \mathrm{S}$ and $35^{\circ}-34^{\circ} \mathrm{S}$, where crustal thicknesses are inferred to increase from $30-35 \mathrm{~km}$ to $40 \mathrm{~km}$, and portions of the SVZ between $34^{\circ}-33^{\circ} \mathrm{S}$ where crustal thicknesses range from $50-55 \mathrm{~km}$. Island-arc-type Jurassic arc with thin crust shows lower ${ }^{87} \mathrm{Sr} /{ }^{86} \mathrm{Sr}$ and higher ${ }^{143} \mathrm{Nd} /{ }^{144} \mathrm{Nd}$ isotopic ratios; SVZ volcanic rocks North of $34^{\circ} \mathrm{S}$, and Late Miocene arc and CVZ with crust $>50-55 \mathrm{~km}$ show more "crust-like" signatures.

Eocene) dacitic-granodioritic and rhyolitic-granitic rocks (Fig. 2a-d). The complete data base is published in Haschke et al. (2002a).

The most mafic main-arc rocks are basaltic andesites (mafic diorites) with high alumina $\left(\mathrm{Al}_{2} \mathrm{O}_{3}\right.$ 18-19.6 wt.\%) and low $\mathrm{MgO}(<5 \mathrm{wt} . \%), \mathrm{Ni}(<30 \mathrm{ppm})$ and $\mathrm{Cr}(<100 \mathrm{ppm})$ contents. They are characterised by mainly overlapping REE patterns with small negative Eu anomalies $\left(\mathrm{Eu} / \mathrm{Eu}^{*} 0.8-0.9\right.$, Fig. 2a). $\mathrm{La} / \mathrm{Yb}(5-7$ to $11-16)$ and $\mathrm{Sr} / \mathrm{Y}(<25$ to $>40)$ ratios increase due to decreasing $\mathrm{Yb}(2.1-2.5$ to $1.4-2.4 \mathrm{ppm})$ and $\mathrm{Y}$ (18-36 to 14-24 ppm) and increasing Sr contents (400500 to $700-900 \mathrm{ppm}$ ) through time, but there are no major differences in REE fractionation between the older (Late Cretaceous) and younger (Mid-Late Eocene) rocks, although the Late Eocene syn/post-tectonic El Abra-Fortuna batholith lacks mafic compositions.

In the back-arc, the alkaline gabbros (Cerros Quimal and Colorado) show slightly higher $\mathrm{MgO}(<6 \mathrm{wt} . \%), \mathrm{Ni}$ (up to $82 \mathrm{ppm}$ ), and $\mathrm{Cr}$ (up to $134 \mathrm{ppm}$ ) contents relative to mafic main-arc rocks, although $\mathrm{MgO}$ contents are still low relative to primitive mantle-derived basalts and for equilibration with mantle peridotite. The back-arc alkaline mafic diorites (78-63 Ma) are characterized by light REE enriched patterns (Fig. 2a) with higher $\mathrm{La} / \mathrm{Yb}$ (11-16) and $\mathrm{Sr} / \mathrm{Y}$ ratios $(>50)$, which may indicate lower partial melting degrees about $100 \mathrm{~km}$ east of the main-arc magmatic front, consistent with their overall LILE and HFSE-enriched signatures.

The andesitic main-arc compositions show more fractionated and overlapping REE patterns (Fig. 2b) with larger negative Eu anomalies $\left(\mathrm{Eu} / \mathrm{Eu}^{*} 0.6-0.9\right)$ than the mafic andesites, and slightly steepening heavy REE patterns through time. Most intermediate compositions are characterized by gradually increasing $\mathrm{La} / \mathrm{Yb}$ (5-7 to $14-26)$ and $\mathrm{Sr} / \mathrm{Y}$ ratios (5-20 to 30-60) through time, due to decreasing $\mathrm{Yb}(2.5-3.7$ to $1.1-1.9 \mathrm{ppm})$ and $\mathrm{Y}(24-32$ to $13-20 \mathrm{ppm})$ concentrations, and increasing $\mathrm{Sr}$ contents (350-470 to 530-920 ppm).

Dacitic-granodioritic main-arc compositions show more fractionated heavy REE patterns and decreasing negative $\mathrm{Eu}$ anomalies with decreasing age (Eu/Eu* 0.5-0.7 to 0.6-1.0; Fig. 2c). $\mathrm{La} / \mathrm{Yb}$ and $\mathrm{Sr} / \mathrm{Y}$ values increase through time, from mostly low $\mathrm{La} / \mathrm{Yb}(6-9)$ and $\mathrm{Sr} / \mathrm{Y}(<20)$ ratios to higher $\mathrm{La} / \mathrm{Yb}(12-17)$ and $\mathrm{Sr} / \mathrm{Y}(15-45)$ in the Mid-Late Eocene. The evolution of increasing $\mathrm{La} / \mathrm{Yb}$ from Late Cretaceous to mid-late Eocene, syn/post-tectonic granodiorites is due to progressively decreasing $\mathrm{Yb}$ (5.9 to $0.8 \mathrm{ppm}$ ) and $\mathrm{Y}$ (57 to $10 \mathrm{ppm}$ ), and increasing Sr contents (mostly 250-350 to 330$670 \mathrm{ppm}$ ). The youngest (late Eocene) syn/post-tectonic granodiorites show the highest $\mathrm{La} / \mathrm{Yb}(18-27)$ and $\mathrm{Sr} / \mathrm{Y}(28$ 69) ratios among dacitic and granodioritic compositions from this arc system (Fig. 2c). 
Table 1. Geochemical characteristics of adakites versus Archean TTG and Late Eocene arc rocks from North Chile

\begin{tabular}{|c|c|c|c|c|}
\hline & \multicolumn{4}{|c|}{ Characteristics of magmas (>60 wt. $\left.\% \mathrm{SiO}_{2}\right)$} \\
\hline & $\begin{array}{l}\text { slab me } \\
\text { Kay (1978) }\end{array}$ & $\begin{array}{l}\text { s ("adakites") } \\
\text { Smith et al. (1979) }\end{array}$ & $\begin{array}{l}\text { Archean TTG } \\
\text { Martin (1987) }\end{array}$ & $\begin{array}{c}\text { syn/post-tectonic } \\
\text { El Abra/Fortuna batholith } \\
\text { Haschke et al. (2002a) }\end{array}$ \\
\hline $\mathrm{La} / \mathrm{Yb}$ & $30-57$ & $108-238$ & $23-156$ & $18-34$ \\
\hline $\mathrm{Sr} / \mathrm{Y}$ & - & $177-344$ & $19-174$ & $19-57$ \\
\hline $\mathrm{Sr}$ & $1783-2600$ & $1520-2650$ & mostly $>300-700$ & $302-612$ \\
\hline $\mathrm{Yb}$ & $0.948-0.633$ & $0.52-0.29$ & $0.13-0.71$ & $0.6-1.5$ \\
\hline $\mathrm{Y}$ & - & 7.7-9.9 & mostly 4-20 & $8.0-22$ \\
\hline $\mathrm{Na}_{2} \mathrm{O}$ & $3.22-3.7$ & $2.23-5.34$ & mostly $4.03-5.14$ & $4.0-5.5$ \\
\hline $\mathrm{Al}_{2} \mathrm{O}_{3}$ & $15.2-15.5$ & $13.7-18.4$ & mostly $15.02-16.29$ & $16.5-17.8$ \\
\hline
\end{tabular}

Rhyolitic-granitic main-arc rocks show extremely fractionated REE patterns with strongly steepening heavy REE patterns with decreasing age, and decreasing negative Eu anomalies (Eu/Eu* 0.2-0.4 to 0.8, Fig. 2d). The oldest rhyolites show mainly low $\mathrm{La} / \mathrm{Yb}(7-12)$ and $\mathrm{Sr} / \mathrm{Y}(1-6)$ ratios, progressively increasing to $\mathrm{La} / \mathrm{Yb}(11-25)$ and $\mathrm{Sr} / \mathrm{Y}$ (418 ) in mid-late Eocene. The Late Eocene syn/post-tectonic granites have the highest $\mathrm{La} / \mathrm{Yb}$ (19-34) and $\mathrm{Sr} / \mathrm{Y}$ ratios (19-54) among rhyolitic-granitic compositions of this paleoarc. These systematic changes are due to progressively decreasing $\mathrm{Yb}(2.2-4.2$ to $1.3-1.5 \mathrm{ppm})$ and $\mathrm{Y}(21-49$ to 17-30 ppm), and increasing Sr contents (mostly 53-156 to $>300 \mathrm{ppm})$ with decreasing age. Even lower $\mathrm{Yb}(0.6-0.7$ $\mathrm{ppm})$ and Y (8-16 ppm) contents, and higher Sr concentrations (224-634 ppm) account for even higher $\mathrm{La} / \mathrm{Yb}$ and $\mathrm{Sr} / \mathrm{Y}$ of the syn/post-tectonic granites. These systematic changes in trace element compositions are accompanied by progressively increasing $\mathrm{Al}$ and $\mathrm{Na}$ contents through time; from $\mathrm{Al}_{2} \mathrm{O}_{3} 15.8$ to $17.0 \mathrm{wt} . \%$, and $\mathrm{Na}_{2} \mathrm{O}$ from 4.0 to $4.5 \mathrm{wt} . \%$ in dacites-granodiorites, and in rhyolites-granites from $\mathrm{Al}_{2} \mathrm{O}_{3}$ 12.7 to 15.6 wt. $\%$, and $\mathrm{Na}_{2} \mathrm{O}$ from 3.3 to $4.1 \mathrm{wt} . \%$.

\subsection{Sr-Nd isotopes}

Initial $\mathrm{Sr}$ and $\mathrm{Nd}$ isotopes of Late Cretaceous-Eocene arc magmatic rocks are overall enriched ("crust-like") relative to melts from the depleted asthenospheric mantle and MORB (Fig. 3). Although ${ }^{87} \mathrm{Sr} /{ }^{86} \mathrm{Sr}$ ratios increase slightly (from $0.7039-0.7045$ to $0.7042-0.7046$ ) and ${ }^{143} \mathrm{Nd} /{ }^{144} \mathrm{Nd}$ ratios decrease slightly (from $0.51265-0.51276$ to 0.51263 0.51271 ), the overall contrast is low and rules out major compositional or structural changes during petrogenesis. A major change is first seen between pre- and post-Miocene magmatic rocks (see Rogers and Hawkesworth, 1989). Higher ${ }^{87} \mathrm{Sr} /{ }^{86} \mathrm{Sr}$ ratios and lower ${ }^{143} \mathrm{Nd} /{ }^{144} \mathrm{Nd}$ ratios may indicate involvement of old (enriched) lithospheric mantle (Rogers and Hawkesworth, 1989) or continental crust (e.g. Hildreth and Moorbath, 1988; Wörner et al., 1988; Davidson et al., 1990; Feeley and Davidson, 1994; Feeley and Hacker, 1995).
However, the higher ${ }^{87} \mathrm{Sr} /{ }^{86} \mathrm{Sr}$ ratios and lower ${ }^{143} \mathrm{Nd} /{ }^{144} \mathrm{Nd}$ ratios lack correlation with decreasing $\mathrm{Sr}$ and increasing $\mathrm{SiO}_{2}$ (Fig. 4a-b), which is commonly attributed to upper crustal contamination during lower pressure differentiation (Rogers and Hawkesworth, 1989; Wörner et al., 1988, 1994; Trumbull et al., 1999). Together with the systematic changes in trace element signatures, this moderate $\mathrm{Sr}$ and $\mathrm{Nd}$ isotopic enrichment in Late Cretaceous-Eocene main-arc magmatic rocks may be due to higher pressure, deep crustal enrichment (see discussion in Rogers and Hawkesworth, 1989).

The back-arc alkaline rocks show overall lower ${ }^{87} \mathrm{Sr} /{ }^{86} \mathrm{Sr}$ ratios (0.7036-0.7046) and higher ${ }^{143} \mathrm{Nd} /{ }^{144} \mathrm{Nd}$ ratios (0.51280-0.51286), relative to the main-arc rocks. This rules out the hypothesis of increasing ${ }^{87} \mathrm{Sr} /{ }^{86} \mathrm{Sr}$ ratios and decreasing ${ }^{143} \mathrm{Nd} /{ }^{144} \mathrm{Nd}$ ratios by recycling old mantle lithosphere during east-propagating Andean arc magmatism, as proposed by Rogers and Hawkesworth (1989). A more detailed elaboration on the geochemistry of Late Cretaceous-Eocene magmatic rocks is published in Haschke et al. (2002a).

\section{Magma source variations}

Overall, the geochemical signatures of Late Cretaceous rocks (high $\mathrm{Yb}$ and $\mathrm{Y}$ concentrations, low $\mathrm{Sr}$ contents, low $\mathrm{La} / \mathrm{Yb}$ and $\mathrm{Sr} / \mathrm{Y}$ ratios) are similar to those of low-Al TTD/TTG (as described by Drummond and Defant, 1990), whereas those of the late Eocene syn/post-tectonic rocks (low $\mathrm{Yb}$ and $\mathrm{Y}$ concentrations, high $\mathrm{Sr}$ contents, high $\mathrm{La} / \mathrm{Yb}$ and $\mathrm{Sr} / \mathrm{Y}$ ratios) resemble those of high-Al TTD/TTG (Table 1).

Partial melts of a deep basaltic source $(\geq 12 \mathrm{kbar})$ will have low $\mathrm{Yb}$ and $\mathrm{Y}$ and high $\mathrm{Sr}$ concentrations (and consequently high $\mathrm{La} / \mathrm{Yb}$ and $\mathrm{Sr} / \mathrm{Y}$ ratios), as seen in the late Eocene syn/post-tectonic granodiorites and granites, if garnet and amphibole but no or only minor plagioclase are residual in the source (Rapp and Watson, 1995; Petford and Atherton, 1996). Residual amphibole is indicated by the middle REE depletion (Fig. 2c-d), whereas high $\mathrm{Sr}_{2} \mathrm{Al}_{2} \mathrm{O}_{3}$ and $\mathrm{Na}_{2} \mathrm{O}$ contents and absent $\mathrm{Eu}$ anomalies indicate lack of plagioclase. 

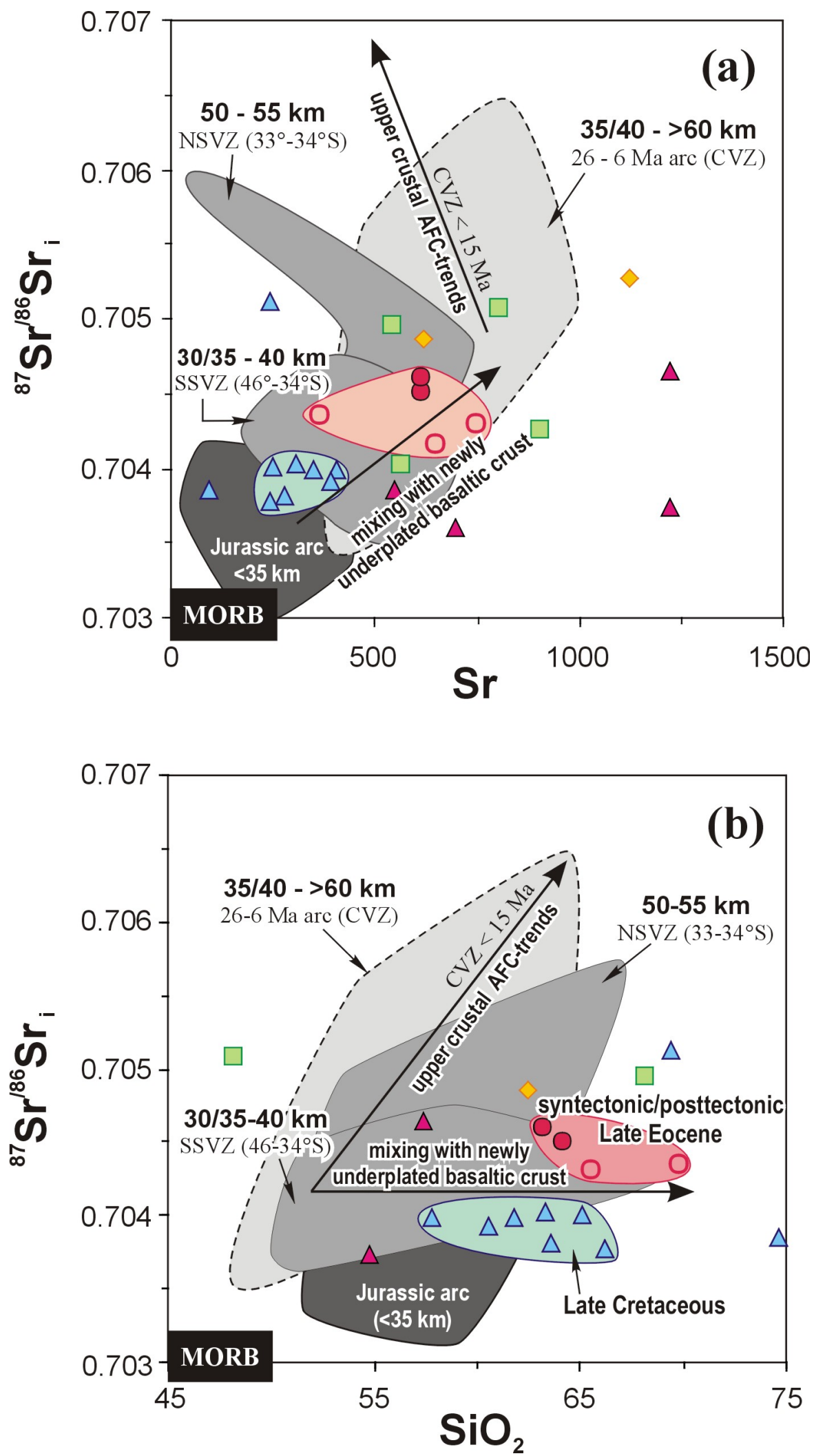

Fig. 4. Initial ${ }^{87} \mathrm{Sr} /{ }^{86} \mathrm{Sr}$ isotopic ratios (a) vs $\mathrm{Sr}$ concentrations [ppm] and (b) vs $\mathrm{SiO}_{2}$ [wt.\%]. Same legend as in Fig. 3 . SVZ and CVZ volcanic rocks show increasing crustal contamination by upper crustal (lower pressure) AFC-trends with crustal thickening. ${ }^{87} \mathrm{Sr} /{ }^{86} \mathrm{Sr}$ and ${ }^{143} \mathrm{Nd} /{ }^{144} \mathrm{Nd}$ isotopic ratios of Late Cretaceous-Eocene magmatic rocks cannot be explained by upper crustal AFC processes, but are consistent with signatures from melting and mixing with partial melts from deep (underplated) mafic crust. 
Even when amphibole is present, more important is the onset of garnet stabilization at higher pressure deeper in the crust. Garnet stabilization changes the melt compositions dramatically with increase in $\mathrm{Si}$ and decrease in $\mathrm{Fe}, \mathrm{Mg}, \mathrm{Y}$ and $\mathrm{Yb}$, like that seen in the late Eocene syn/post-tectonic granitoids after Incaic crustal shortening, in experimental highAl TTD/TTG's at 12 kbar (Rushmer, 1993; Rapp and Watson, 1995), and in the granitoid Cordillera Blanca batholith in Peru (Atherton and Petford, 1993; Petford and Atherton, 1996). The latter was interpreted as being generated by melting newly underplated garnet and/or amphibole-bearing (hydrous) basaltic crust.

The compositions of these melts are also similar to primary dacitic melts from subducting oceanic crust (also known as "adakites", Table 1). However, adakites are generally expected in forearc regions, not above the arc crustal keel (Atherton and Petford, 1993), and they generally lack such a systematic geochemical evolution of increasing $\mathrm{La} / \mathrm{Yb}$ ratios as the one seen in Late Cretaceous-Eocene arc magmatic rocks. Furthermore, the abrupt $\mathrm{La} / \mathrm{Yb}$ increase in the syn/post-tectonic late Eocene granodiorites and granites occurred coeval with Incaic shortening and thickening of the crust. It is therefore plausible that the latest (late Eocene) increase in $\mathrm{La} / \mathrm{Yb}$ monitored continental crustal dynamics rather than slab melting. Following this argument, it is conceivable that the gradual increase in $\mathrm{La} / \mathrm{Yb}$ ratios prior to late Eocene crustal shortening (from Late Cretaceous to MidEocene) also reflects gradual crustal thickening. However, the tectonic record from this period lacks evidence of crustal shortening, and therefore the crustal thickening inferred may be due to other processes such as successive magmatic underplating.

I envisage a model which takes both increasing crustal thickening and mixing between mantle-derived basalts and crustal melts from newly underplated basaltic crust into account. Successive underplating and stalling of hot mantlederived basalts at or near the base of the crust triggers two main parallel operating processes:

(1) progressive deepening of the MASH crust-mantle boundary zone (MASH = melting, assimilation, storage, homogenization, after Hildreth and Moorbath, 1988) through time and transforming initial lower pressure gabbroic to higher pressure garnet- and amphibolebearing source mineralogies, and

(2) remelting and increasing crustal melt proportions from newly underplated basaltic lower crust. The ability of incoming basalt to melt pre-existing underplate (amphibolite) has been investigated recently. Results suggest that the amount of incoming mantle basalt need not to be large to promote melting, and that the timescale of melting will be in the order of thousands of years only (Petford and Gallagher, 2001).

In this model, the Late Cretaceous andesite-dacite-rhyolite (island-arc type) suite from North Chile represents mainly derivatives from mantle-derived basalts with little or no in- fluence from crustal melt. Recharging hot mantle basalts into the MASH zone causes remelting (recycling) below the newly underplated basaltic crust at greater depth. The recharging mafic melt will hybridise with the more silicic crustal melts from the newly underplated basaltic crust, producing hybrid melts with geochemical and isotopic compositions reflecting the amount of hybridisation between mafic mantle and silicic crustal melt rather than the original source signature. Successive underplating and ponding of hot mantle basalts throughout the more than 40 m.y. that this arc was active probably lead to substantial thermal weakening and remelting of the mafic arc crustal base. Such rheologically and thermally weakened arc crust provides ideal mechanical conditions for shortening of arc crust during the late Eocene transpressional tectonic regime (Incaic phase, Döbel et al., 1992). The declining presence and complete lack of mafic main-arc igneous rocks in the Late Eocene syn/post-tectonic El Abra-Fortuna granodiorites and granites may reflect primary crustal melts with little or no contribution of mantlederived basalts, since subduction-related magmatism ceased after Incaic deformation.

This model can account for the gradually increasing silicic crustal melt proportions as seen in main-arc magmatic rocks between Late Cretaceous and Late Eocene, but also accounts for the relatively constant $\mathrm{Sr}$ and $\mathrm{Nd}$ isotopic compositions with time, as the (lower) crustal source consists of freshly underplated mantle-derived basalts with little variation in composition and age.

\subsection{Estimating paleo-arc crustal thicknesses (Late Creta- ceous - Late Eocene)}

The main-arc REE patterns and initial $\mathrm{Sr}$ and $\mathrm{Nd}$ isotopic signatures of Late Cretaceous-Mid Eocene main-arc magmatic rocks in North Chile (prior to Incaic deformation) are similar to those seen in the southern SVZ between $46^{\circ}-34^{\circ} \mathrm{S}$ (Fig. 3 and $4 a-b$ ), where crustal thicknesses are inferred to increase from 30-35 to about $40 \mathrm{~km}$ (Hildreth and Moorbath, 1988). Geochemical and isotopic characteristics of late Eocene syn/post-tectonic granitoids also overlap the field of late Oligocene volcanic rocks in the Maricunga belt $\left(26^{\circ}\right.$ $28^{\circ} \mathrm{S}$, Kay et al., 1994), and that of the southern SVZ between $35^{\circ}-34^{\circ} \mathrm{S}$, where crustal thicknesses of about $40 \mathrm{~km}$ were estimated (Hildreth and Moorbath, 1988).

SVZ volcanic magmas between $34^{\circ}-33^{\circ} \mathrm{S}$ are thought to have travelled through thicker crust $(50-55 \mathrm{~km})$, and most initial ${ }^{87} \mathrm{Sr} /{ }^{86} \mathrm{Sr}$ and ${ }^{143} \mathrm{Nd} /{ }^{144} \mathrm{Nd}$ ratios of late Eocene syn/post-tectonic granitoids are lower and higher, respectively, or only partly overlap this SVZ field (Fig. 3 and 4a-b). Using these analogue along-arc variations in geochemistry and crustal thicknesses in the SVZ, I estimate roughly that mafic underplating in the Late Cretaceous-Eocene paleoarc may have thickened the arc crust by $5-10 \mathrm{~km}$, from 30 $35 \mathrm{~km}$ to about $40 \mathrm{~km}$. Subsequent late Eocene Incaic shortening and thickening of the crust lowered the arc crustal base to about $45 \mathrm{~km}$. This estimate is consistent with balanced 

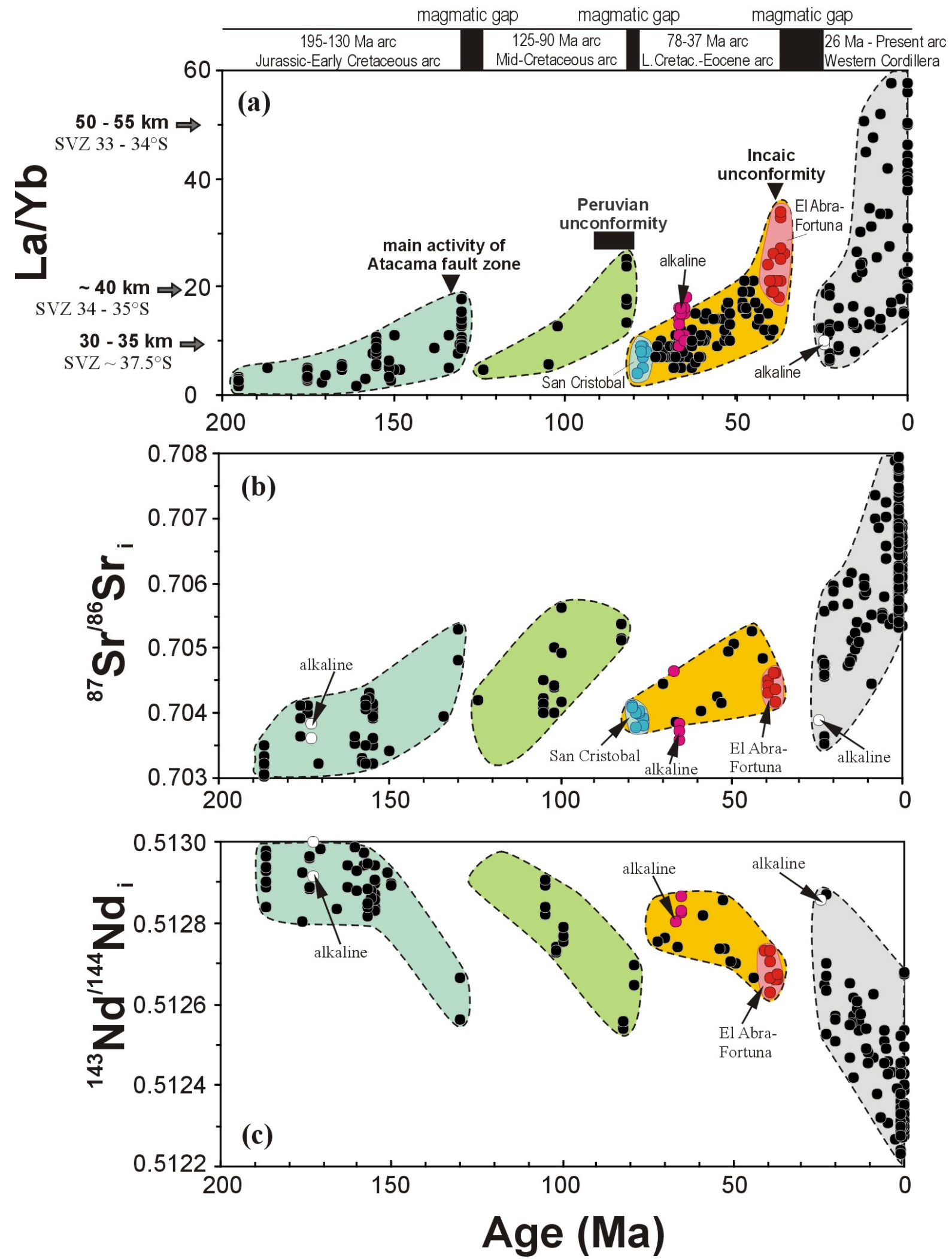

Fig. 5. Plot of age of Andean magmatic rocks (a) vs La/Yb, (b) vs initial ${ }^{87} \mathrm{Sr} /{ }^{86} \mathrm{Sr}$ ratios, and (c) vs ${ }^{143} \mathrm{Nd} /{ }^{144} \mathrm{Nd}$-isotopic ratios, showing correlation of higher La/ $\mathrm{Yb}$ ratios and higher ${ }^{87} \mathrm{Sr} /{ }^{86} \mathrm{Sr}$ and lower ${ }^{143} \mathrm{Nd} /{ }^{144} \mathrm{Nd}$ isotopes with decreasing age in each arc system. Episodes of transtensional or transpressional tectonic activity are followed by magmatic gaps of 5-10 m.y., and subsequent stepwise eastward migration of main-arc magmatic activity. 
across-arc structural sections of Incaic crustal shortening in this region (7-8 km, Haschke and Günther, 2002).

This correlation is consistent with results from numerical trace element modeling. Simulations of melting lower crustal basaltic source mineralogies at variable depth suggest that the late Eocene syn/post-tectonic granitoids can be explained by partial melting of garnet-bearing amphibolite with up to 10 wt.\% garnet (Haschke et al., 2002a), reflecting pressures $\geq 12$ kbar or $\geq 40 \mathrm{~km}$ crustal thickness (Rushmer, 1993; Rapp and Watson, 1995). Eclogitic residues (>10 wt.\% garnet) at pressures $\geq 15 \mathrm{kbar}$ (or $\geq 50 \mathrm{~km}$ crustal thickness) produce higher $\mathrm{La} / \mathrm{Yb}$ and $\mathrm{Sr} / \mathrm{Y}$ ratios (Rapp and Watson, 1995) than those seen in the late Eocene syn/post-tectonic granitoids, suggesting that late Eocene arc crustal thicknesses after Incaic crustal shortening (38.5 Ma, Döbel et al., 1992) were less than $50 \mathrm{~km}$.

Comparing the Late Cretaceous-Eocene evolutionary geochemical and isotopic patterns with those of other Andean arc magmatic rocks also revealed that increasing $\mathrm{La} / \mathrm{Yb}$ ratios and higher ${ }^{87} \mathrm{Sr} /{ }^{86} \mathrm{Sr}$ ratios and lower ${ }^{143} \mathrm{Nd} /{ }^{144} \mathrm{Nd}$ ratios through time are diagnostic of all paleo-arc systems in North Chile (Fig. 5a-c).

Within each arc-magmatic episode, increasing $\mathrm{La} / \mathrm{Yb}$ ratios correlate with (tectonic and magmatic) arc crustal thickening except for the Jurassic arc. Regional geologic constraints from the oldest Andean magmatic arc system show no evidence of crustal shortening and/or significant crustal thickening (Scheuber et al., 1994), consistent with overall low $\mathrm{La} / \mathrm{Yb}$ ratios which do not appear to increase with decreasing eruption age (Fig. 5a). The first indication of significant crustal thickening comes from the mid-Cretaceous arc, where the Peruvian unconformity indicates shortening and thickening of the crust between 90-80 Ma (Scheuber et al., 1994). Even though this tectonomagmatic period is not well constrained (due to lack of outcrops), the overall trend of increasing $\mathrm{La} / \mathrm{Yb}$ ratios is clear. From $\sim 200 \mathrm{Ma}$-Present, this pattern restarted each time the axis of main-arc magmatic activity migrated to the east. The constraints of this pattern on the plate tectonic changes during the Andean orogeny are discussed in a separate paper (see Haschke et al., 2002b).

In spite of repeated arc shifts, basaltic underplating from 200 Ma-Present implies that large amounts of basaltic crust were added to the base of the continental crust. This will have significant effects on the seismic nature of the lower crust and crust-mantle boundary. P-wave velocities $(\mathrm{Vp})$ in the lowermost $20 \mathrm{~km}$ of the central Andean crustal column beneath the Coastal Cordillera, Longitudinal Valley, Chilean Precordillera and Western Cordillera at $23.5^{\circ} \mathrm{S}$ range from $7.3-7.7 \mathrm{~km} / \mathrm{s}$ (Schmitz et al., 1999). Both the lowermost crustal thickness and the range of $\mathrm{Vp}$ shown are well within the expected range for crustal thickening (up to $25 \mathrm{~km}$ ) and Vp (7.1-7.8 km/s) predicted by Furlong and Fountain (1986).

\section{Discussion - implications on Archean crustal growth}

Subduction-related magmatism at convergent plate margins is the main mechanism for crustal growth (Rudnick, 1995). The key to relate the evolutionary geochemical patterns shown in this study to Archean crustal growth lies in the temporal transition from low-Al to high-Al TTD/TTG. The low-Al TTD/TTG type rocks appear to relate to thin island-arc type (Late Cretaceous) crust, whereas high-Al TTD/TTG type rocks tend to accompany overthickened orogenic ( $>40 \mathrm{~km}$, late Eocene) crust. Main-arc rocks with intermediate ages are characterised by transitional compositions, intermediate between low-Al and high-Al TTD/TTG, consequently reflecting intermediate crustal thicknesses.

Such transitions are characteristic of the entire Andean orogeny (200 Ma-Present, Fig. 5a-c). One important implication is that Archean high-Al TTD/TTG crust may be associated with melting of, or contamination within, the deep arc crust $(>40 \mathrm{~km})$. As a rule of thumb, these patterns suggest: The thicker the arc crust, the more do major and trace element compositions of arc magmatic rocks resemble that of Archean high-Al TTD/TTG or adakitic rocks. It is clear that neither the low-Al type is restricted to the Phanerozoic, nor the high-Al type to the Precambrian period (unlike proposed by Drummond and Defant, 1990).

If correct, then Archean TTD/TTD crust must have been thicker, or, in other words, orogenic crust was more widespread than today, and if remelting the mafic base of thick arc crust was a key mechanism for TTG/TTD type crustal growth, which mechanism was responsible for thickening the crust during Archean times?

Recent investigations of modern anomalous thick orogenic crust (Andes, Himalaya) indicate that crustal shortening is very efficient in thickening the crust (e.g. Allmendinger et al., 1997). One important requirement for crustal shortening at convergent plate margins is rapid convergence (e.g. Nazca plate versus South American plate: $8.7 \mathrm{~cm} / \mathrm{a}$; Scheuber and Giese, 1999). Even higher plate motion and convergence rates are inferred for the Archean, as higher heat flow in early Earth's history presumably induced fast rifting and consequently fast subduction of smaller and hotter plates (Martin, 1999). Slab melting may have been characteristic for the Archean, but can slab melting alone account for rapid (adakitic or TTG/TTD type) crustal growth ? Results of trace element modeling of adakites from previous authors and experimental petrologic work both suggest that adakites are products of very low partial melting degrees (3-7 vol.\%; Kay, 1978; Smith et al., 1979; Kay et al., 1993). If this is correct, how can adakites alone explain rapid crustal growth in the Archean? Even assuming that adakite production was more abundant in early Earth's history, it probably could not have produced the large amount of Archean high-Al TTD/TTG type continental crust.

I propose that non-collisional as well as collisional (Andean-type and/or Himalayan-type) tectonic crustal shortening and thickening was more widespread and common in the Archean than today, and that Archean crust was over- 
all thicker than today $(46-52 \mathrm{~km}$ : Artemieva and Mooney, 2001; $\geq 35-50$ km: Kröner, 1991), and mostly basaltic (Abbott et al., 1997). Crustal shortening may have been facilitated by the generally assumed higher Archean thermal gradients, since warmer lithosphere is rheologically weaker and therefore easier to deform. This is also consistent with the general accepted idea that Archean plate motions and convergence rates were faster than today (e.g. Martin, 1999), since more rapid convergence probably caused strong coupling inducing crustal shortening in the overlying plate. If this is true, then Precambrian high-Al TTD/TTG crust reflects remnants of thick ancient (Andean or Himalayan-type) orogens. Much of Archean (lower) orogenic crust may have been lost to the mantle by subsequent delamination through time (Kay and Kay, 1991).

This model does not rule out slab melting during early Earth's history, but it supports previous work highlighting the importance of magmatic underplating (e.g. Atherton and Petford, 1993; Petford and Atherton, 1996; Petford and Gallagher, 2001) in TTG/TTD generation. Regardless of which process dominated the generation of high-Al Archean TTD/TTG crust (slab melting or recycling of mafic underplate), both had to operate efficiently and on a large scale in order to account for the distribution of existing Archean high-Al TTD/TTG crust.

Acknowledgements. I am grateful for the support of this project by the Sonderforschungsbereich 267 (Deformationsprozesse in den Anden) at the FU Berlin, and for two anonymous reviewers for significantly improving the quality of this manuscript.

\section{References}

Abbott, D. H., Drury, R., and Mooney, W. D.: Continents as lithological icebergs: the importance of buoyant lithospheric roots, Earth Planet. Sci. Lett., 149, 15-27, 1997.

Allmendinger, R. W., Jordan, T. E., Kay, S. M., and Isacks, B. L.: The evolution of the Altiplano-Puna plateau of the Central Andes, Annual Reviews in Earth Planetary Sciences, 25, 139-174, 1997.

Artemieva, I. M. and Mooney, W. D.: Thermal thickness and evolution of Precambrian lithosphere: A global study, J. Geophys. Res., 106 (B8), 16 387-16414, 2001.

Atherton, M. P., and Petford, N.: Generation of sodium-rich magmas from newly underplated basaltic crust, Nature, 362, 144146, 1993.

Charrier, R. and Reutter, K.-J.: The Purilactis Group of Northern Chile: boundary between Arc and Backarc from Late Cretaceous to Eocene, in Reutter, K.-J., Scheuber, E., and Wigger, P. (Eds.): Tectonics of the Southern Central Andes, Berlin, Springer, 189202, 1994

Coira, B., Davidson, J., Mpodozis, C., and Ramos, V. A.: Tectonic and magmatic evolution of the Andes of Northern Argentina and Chile, Earth Scienc. Rev., 18, 303-332, 1982.

Davidson, J. P., McMillan, N., Moorbath, S., Wörner, G., Harmon, R., and Lopez-Escobar, L.: The Nevados de Payachata volcanic region $\left(18^{\circ} \mathrm{S} / 69^{\circ} \mathrm{W}, \mathrm{N}\right.$. Chile) II. Evidence for widespread crustal involvement in Andean magmatism, Contrib. Mineral. Petrol., 105, 412-432, 1990.
Döbel, R., Hammerschmidt, K., and Friedrichsen, H.: Implication of ${ }^{40} \mathrm{Ar} /{ }^{39} \mathrm{Ar}$ dating of early Tertiary volcanic rocks from the North-Chilean Precordillera, Tectonophysics, 202, 55-81, 1992.

Drummond, M. S. and Defant, M. J.: A model for trondhjemitetonalite-dacite genesis and crustal growth via slab melting: Archean to modern comparisons, J. Geophys. Res., 95 (B13), 21 503-21 521, 1990

Feeley, T. C. and Davidson, J. P.: Petrology of Calc-Alkaline Lavas at Volcan Ollague and the Origin of Compositional Diversity at Central Andean Stratovolcanoes, J. Petrol., 35 (5), 1295-1340, 1994.

Feeley, T. C. and Hacker, M. D.: Intracrustal derivation of Na-rich andesitic and dacitic magmas - an example from volcan Ollague, Andean central volcanic zone, J. Geol., 103 (2), 213-225, 1995.

Furlong, K. and Fountain, D. M., 1986, Continental crustal underplating: thermal considerations and seismic-petrological consideration, J. Geophys. Res., 91, 8285-8294.

Günther, A., Haschke, M. R., Reutter, K.-J., and Scheuber, E.: Kinematic evolution and structural geometry of the Chilean Precordillera $\left(21.5-23^{\circ} \mathrm{S}\right)$ : inversional tectonics in the Late Cretaceous-Paleogene magmatic arc, Abstracts, Terra Nostra, 98/5, 58-59, 1998.

Haschke, M., Siebel, W., Günther, A., and Scheuber, E.: Repeated crustal thickening and recycling during the Andean orogeny in North Chile $\left(21^{\circ}-26^{\circ} \mathrm{S}\right)$, J. Geophys. Res., 107 (B1), DOI 10.1029/2001JB000328, 2002a.

Haschke, M., Scheuber, E., Günther, A., and Reutter, K.-J.: Evolutionary cycles during the Andean orogeny: Repeated slab breakoff and flat subduction?, Terra Nova, 14 (1), 49-56, 2002 b.

Haschke, M. and Günther, A.: Balancing tectonic versus magmatic arc crustal thickening, Geology, in review, 2002.

Hildreth, W. and Moorbath, S.: Crustal contributions to arc magmatism in the Andes of Central Chile, Contrib.Mineral.Petrol., 98, 455-489, 1988.

Jensen, A.: El sobre escurrimiento de Cerro Laberinto, IV. Congr. Geol. Chileno, Actas, A2, 84-103, 1985.

Kay, R. W.: Aleutian magnesian andesites: Melts from subducted Pacific ocean crust, J. Volcanol. Geotherm. Res, 4, 117-132, 1978.

Kay, R. W. and Kay, S. M.: Creation and destruction of lower continental crust, Geol. Rundsch., 80/2, 259-278, 1991.

Kay, S. M., Mpodozis, C., Ramos, V. A., and Munizaga, F.: Magma source variations for Mid-Tertiary magmatic rocks associated with a shallowing subduction zone and a thickening crust in the Central Andes $\left(28^{\circ}-33^{\circ} \mathrm{S}\right)$, in: Harmon, R. S. and Rapela, C. W. (Eds.): Andean magmatism and its tectonic setting, Boulder, CO, Geol. Soc. Am. Spec. Pap., 265, 113-137, 1991.

Kay, S. M., Ramos, V. A., and Marques, M.: Evidence in Cerro Pampa volcanic rocks for slab-melting prior to ridge-trench collision in Southern South America, J. Geology, 101, 703-714, 1993.

Kay, S. M., Mpodozis, C., Tittler, A., and Cornejo, P.: Tertairy magmatic evolution of the Maricunga Mineral Belt in Chile, Int. Geol. Rev., 36, 1079-1112, 1994.

Kröner, A.: Tectonic evolution in the Archean and Proterozoic, in: LeMouel, J. L. (Ed.): Beyond Plate Tectonics, Tectonophysics, 18, 393-410, 1991.

Maksaev, V.: Metallogeny, geological evolution, and thermochronology of the Chilean Andes between latitudes $21^{\circ}$ and $26^{\circ} \mathrm{S}$ and the origin of major porphyry copper deposits, $[\mathrm{PhD}-$ thesis]: Dalhousie University, Canada, 554p, 1990. 
Martin, H.: Petrogenesis of Archean trondhjemites, tonalites and granodiorites from eastern Finland: major and trace element geochemistry, J. Petrol., 28, 921-953, 1987.

Martin, H.: Adakitic magmas: modern analogues of Archean granitoids, Lithos, 46, 411-429, 1999.

Petford, N. and Atherton, M.: Na-rich partial melts from newly underplated basaltic crust: the Cordillera Blanca Batholith, Peru, J. Petrol., 37 (6), 1491-1521, 1996.

Petford, N. and Gallagher, K.: Partial melting of mafic (amphibolitic) lower crust by periodic influx of basaltic magma, Earth Planet. Sci. Lett., 193, 483-499, 2001.

Rapp, R. P. and Watson, E. B.: Dehydration melting of metabasalt at 8-32 kbar: Implications for continental growth and crust-mantle recycling, J. Petrol., 36 (4), 891-931, 1995.

Reutter, K.-J., Scheuber, E., and Helmcke, D.: Structural evidence of orogen-parallel strike slip displacements in the Precordillera of northern Chile, Geol. Rundsch., 80/1, 135-153, 1991.

Rogers, G. and Hawkesworth, C. J.: A geochemical traverse across the North Chilean Andes: evidence for crust generation from the mantle wedge, Earth Planet. Sci. Lett., 91, 271-285, 1989.

Rudnick, R. L.: Making continental crust, Nature, 378, 571-578, 1995.

Rushmer, T.: Experimental high pressure granulites: some applications to natural mafic xenolith suites and Archean granulite terranes, Geology, 21, 411-414, 1993.

Scheuber, E. and Reutter K.-J.: Magmatic arc tectonics in the Central Andes between $21^{\circ}$ and $25^{\circ} \mathrm{S}$, Tectonophysics, 205, 127140, 1992.

Scheuber, E., Bogdanic, T., Jensen, A., and Reutter, K.-J.: Tectonic development of the North Chilean Andes in relation to plate convergence and magmatism since the Jurassic, in: Reutter, K.-J., Scheuber, E., and Wigger, P. (Eds.): Tectonics of the Southern
Central Andes, Berlin, Springer, 121-139, 1994.

Scheuber, E. and Giese, P.: Architecture of the Central Andes a compilation of geoscientific data along a transect at $21^{\circ} \mathrm{S}, \mathrm{J}$. South Am. Earth Sci., 12, 103-107, 1999.

Smith, I. E., Taylor, S. R., and Johnson, R. W.: REE-fractionated trachytes and dacites from Papua New Guinea and their relationship to andesite petrogenesis, Contribution to Mineralogy and Petrology, 69, 227-233, 1979.

Trumbull, R. B., Wittenbrink, R., Hahne, K., Emmermann, Büsch, W., Gerstenberger, H., and Siebel, W.: Evidence for late Miocene to recent contamination of arc andesites by crustal melts in the Chilean Andes $\left(25-26^{\circ} \mathrm{S}\right)$ and its geodynamic implications, J. South Am. Earth Sci., 12 (2), 135-155, 1999.

Wigger, P. J., Schmitz, M., Araneda, M., Asch, G., Baldzuhn, S., Giese, P., Heinsohn, W.-D., Martinez, E., Ricaldi, E., Rüwer, P., and Viramonte, J.: Variation in the crustal structure of the southern central Andes deduced from seismic refraction investigations, in: Reutter, K.-J., Scheuber, E., and Wigger, P. (Eds.): Tectonics of the Southern Central Andes, Berlin, Springer, 2348, 1994.

Wörner, G., Harmon, R. S., Davidson, J., Moorbath, W., Turner, D. L., McMillan, N., Nye, C., Lopez-Escobar, L., and Moreno, H.: The Nevados de Payachata volcanic region $\left(18^{\circ} \mathrm{S} / 69^{\circ} \mathrm{W}\right.$, N. Chile) 1. Geological, geochemical and isotopic observations, Bull. Volcanol., 50, 287-303, 1988.

Wörner, G., Moorbath, S., Horn, S., Entenmann, J., Harmon, R. S., Davidson, J. P., and Lopez-Escobar, L.: Large- and finescale geochemical variations along the Andean arc of Northern Chile (17.5-22 ${ }^{\circ}$ S), in: Reutter, K.-J., Scheuber, E., and Wigger, P. (Eds.): Tectonics of the Southern Central Andes, Berlin, Springer, 69-76, 1994. 